\title{
Lavandula stoechas (L) a Very Potent Antioxidant Attenuates Dementia in Scopolamine Induced Memory Deficit Mice
}

OPEN ACCESS

Edited by:

Tahir Ali,

Gyeongsang National University,

South Korea

Reviewed by:

Simone Carradori,

Università "G. d'Annunzio" di

Chieti-Pescara, Italy

Muhammad Nadeem Ashraf,

University of Alberta, Canada

*Correspondence:

Aamir Mushtad

aamir_mushtaq@hotmail.com

Specialty section:

This article was submitted to Ethnopharmacology,

a section of the journal

Frontiers in Pharmacology

Received: 27 February 2018

Accepted: 08 November 2018

Published: 23 November 2018

Citation:

Mushtaq A, Anwar R and Ahmad M (2018) Lavandula stoechas

(L) a Very Potent Antioxidant Attenuates Dementia in Scopolamine

Induced Memory Deficit Mice.

Front. Pharmacol. 9:1375.

doi: 10.3389/fphar.2018.01375

\author{
Aamir Mushtaq ${ }^{1,2 *}$, Rukhsana Anwar ${ }^{1}$ and Mobasher Ahmad ${ }^{1,2}$ \\ ${ }^{1}$ Department of Pharmacology, Punjab University College of Pharmacy, University of the Punjab, Lahore, Pakistan, ${ }^{2}$ Gulab \\ Devi Institute of Pharmacy, Gulab Devi Educational Complex, Lahore, Pakistan
}

The objective of the current project was to explore the pharmacotherapeutic role of Lavandula stoechas $(L)$ for the management of dementia. Dementia is considered a global challenge of current century seeking special attention of pharmacologists to explore its best remedies. Methanolic extract of aerial parts of $L$. stoechas was tested for phytochemical analysis along with free radical scavenging activity. Behavioral studies were performed on scopolamine induced amnesic mice by using elevated plus maze (EPM), light and dark test and hole board paradigms. Biochemical investigations were made after decapitating the mice. Their brains were isolated for biochemical estimation of acetylcholinesterase (AChE), malondialdehyde (MDA), superoxide dismutase (SOD), catalase (CAT), and glutathione $(\mathrm{GSH})$. Phytochemical study ensured the presence of total phenolic contents (285.91 $\pm 0.75 \mathrm{mg}$ of GAE/g of extract), total flavonoids (134.06 $\pm 0.63 \mathrm{mg}$ of RE/g of extract), total tannins (149.60 $\pm 0.93 \mathrm{mg}$ of TAE/g of extract) and free radical scavenging activity $\left(\mathrm{I}_{50}\right.$ value $=76.73 \mu \mathrm{g} / \mathrm{ml}$ found by $\mathrm{DPPH}$ method). Behavioral studies indicated that animals of GVII showed higher inflexion ratio $(0.40 \pm 0.03)$ for EPM, spent most of time $(227.17 \pm 2.13 \mathrm{~s})$ in dark area of light dark test and had many hole pockings (39.83 \pm 1.88 ) for hole board paradigm. Moreover, biochemical studies revealed that methanolic extract of $L$. stoechas (800 mg/kg/p.o.) significantly $(P<0.001)$ reduced brain AChE and MDA levels while improved SOD, CAT, and GSH levels. Thus the findings suggest that $L$. stoechas stabilizes memory by enhancing cholinergic neurotransmission and by providing defense against oxidative stress in mice brain.

Keywords: dementia, neurodegeneration, AChE, L. stoechas, elevated plus maze

\section{INTRODUCTION}

Dementia results from neurodegenerative insult in brain neurons. Neurodegeneration not only leads to the impairment of memory but also alters the social and behavioral compliance. Cholinergic hypothesis (Francis et al., 1999) describes the pathogenesis of dementia, according to which severity of the disease is coupled with neuronal damages in septohippocampal cholinergic system (Giovannini et al., 1997) associated with learning and cognitions (Ballard et al., 2005). Acetyl 
cholinesterase inhibitors like donepezil, galantamine, rivastigmine (Bejar et al., 1999) and tacrine can be used for the symptomatic management of mild dementia but they have little therapeutic success because they do not prevent neurodegeneration and are associated with serious adverse effects (Hake, 2001). Herbal remedies are considered more safe, gentle and reliable in enhancing memory and cognitive functions (Bhattacharjee et al., 2015). Roughly, 150 traditional plants and herbs have been used so for, either singly or in combined preparations to stop neurodegeneration in brain (Adams et al., 2007). This is of great worth to identify the active constituent for the management of dementia and cognitive disorders which will definitely enhance the practice of customary herbs in the field of neuropharmacology (Kumar et al., 2012).

Lavandula stoechas L. (Lamiaceae) has been extensively used by traditional healers for the management of CNS disorders including epilepsy, dementia, and migraine (Hakeem et al., 1991). This is also known as the broom of the brain. Its aerial parts have been extensively studied for phytochemical work (Gilani et al., 2000). The present research work was aimed to explore the pharmacological basis of enhancement of memory to strengthen the folk and traditional use of L. stoechas as a memory enhancer.

\section{MATERIALS AND METHODS}

\section{Drugs and Chemicals}

Acetic acid (71251), 2,2-diphenyl-1-picrylhydrazyl (DPPH) (D9132), acetyl thiocholine iodide (A22300), carboxy methyl cellulose (CMC) (419273), 5,5'-dithiobis-2-nitrobenzoic acid (DTNB) (D218200), aluminum chloride (563919), ascorbic acid (A0278), chloroform (C2432), ethanol (E7023), Folin-Ciocalteu reagent (FCR) (F9252), gallic acid (G7384), methanol (34860), $n$-butanol, nitro blue tetrazolium (NBT) (N5514), phenyl methanesulfonate (PMS) (495085), superoxide dismutase (SOD) (S9697), hydrogen peroxide $\left(\mathrm{H}_{2} \mathrm{O}_{2}\right)(16911)$, potassium acetate (P1190), potassium dichromate (P5271), reduced nicotinamide adenine dinucleotide (NADH) (N8129), rutin (R5143), sodium carbonate (S7795), sodium dodecyl sulfate (436143), tannic acid (403040), trichloracetic acid (TCA) (T6399) and thiobarbituric acid (TBA) (T5500) all were procured from Sigma-Aldrich, Ms Traders, Lahore Pakistan. Piracetam and scopolamine was donated by Jiangxi Yuehua Pharmaceutical, China and Merck Pharmaceutical Pvt. Ltd. Pakistan, respectively, upon special request. All chemicals of analytical grades were used in this research.

\section{Preparation of Plant Extract}

Dried aerial parts of $L$. stoechas were purchased from local market of Lahore, Pakistan and were identified by Department of Botany GC-University, Lahore. Plant specimen was preserved in herbarium with voucher number GC.Herb.Bot.3386. For extraction, dried aerial parts were ground into coarse size powder and $1 \mathrm{~kg}$ of it was soaked into $5 \mathrm{~L}$ methanol (99.5\%) in glass jar for 3 days. It was then filtered first by muslin cloth and then through Whatman No. 1 filter paper. Filtrate was concentrated in buchi rotavapor and residue was again macerated in recovered methanol for another 3 days. In this way, after three consecutive soakings concentrated filtrates were mixed up and dried in dry heat oven at $37^{\circ} \mathrm{C}$. Finally dark green colored thick extract was obtained which was labeled after sealing in glass jar and put into refrigerator at $4^{\circ} \mathrm{C}$ temperature. Percentage yield was calculated as;

$\%$ Age yield $=$ Weight of extract $(\mathrm{g}) /$ Weight of plant material $(\mathrm{g}) \times 100$

\section{Phytochemical Analysis of Plant Extract}

Preliminary phytochemical testing of L. stoechas methanolic extract was performed to explore the major phytochemical classes actually responsible for anti-oxidant and anti-amnesic activities. Proteins, carbohydrates, alkaloids, glycosides, flavonoids, steroids, terpenoids, saponins, tannins, phenols, quinones, phytosterol, terpenes, and fixed oil were tested qualitatively (Mushtaq et al., 2013).

\section{Estimation of Phenolic Contents}

Total phenolic contents of plant extract were determined by using FCR as described by Kumaran and Karunakaran (2007). For determination of total phenols sample solution was prepared by mixing $100 \mu \mathrm{l}$ of $L$. stoechas methanolic extract $(100 \mu \mathrm{g} / \mathrm{ml})$, $500 \mu \mathrm{l}$ of FCR and $1.5 \mathrm{ml}$ of $20 \%$ sodium carbonate. Solution was shaken vigorously in vortex mixer after making the volume of solution $10 \mathrm{ml}$ by adding distilled water and mixture was incubated for $2 \mathrm{~h}$. Similarly, standard solution was prepared by adding $100 \mu \mathrm{l}$ of different dilutions of gallic acid (50, 100, 150, $200,250,300,350$, and $400 \mu \mathrm{g} / \mathrm{ml}$ ) separately in reaction mixture instead of $L$. stoechas extract. Then absorbance of both sample and standard solutions were determined at $765 \mathrm{~nm}$ against blank. All readings were taken in triplicates and total phenolic contents in plant extract were expressed as gallic acid equivalent (GAE) by drawing gallic acid calibration curve. Following formula was used to find total phenol contents in plant extract; $C=C i \times V / W$

$C=$ total phenolic content in $\mathrm{mg} / \mathrm{g}, \mathrm{Ci}=$ concentration of gallic acid established from calibration curve in $\mathrm{mg} / \mathrm{ml}, V=$ volume of extract in $\mathrm{ml}$, and $W=$ weight of plant extract in gram.

\section{Estimation of Total Flavonoids}

Flavonoid contents were found by using aluminum chloride method as proposed by Kumaran and Karunakaran (2007). Stock solutions were prepared separately by taking $0.5 \mathrm{ml}$ of plant extract $(1 \mathrm{mg} / \mathrm{ml})$ and standard rutin $(10-100 \mu \mathrm{g} / \mathrm{ml})$. To each test tube, $1.5 \mathrm{ml}$ of methanol, $0.10 \mathrm{ml}$ potassium acetate, $0.10 \mathrm{ml}$ aluminum chloride and $2.8 \mathrm{ml}$ distilled water was added with constant shaking. All solutions were filtered and absorbance was taken at $510 \mathrm{~nm}$. A calibration curve was drawn for rutin and total flavonoid contents were found as mg rutin equivalents (RE)/g dry extract.

\section{Estimation of Total Tannins}

Tannins in plant extract were determined by modified FolinCiocalteu's method by preparing $0.1 \mathrm{ml}$ standard tannic acid solutions of different dilutions (50, 100, 150, 200, 250, 300, 400, and $500 \mu \mathrm{g} / \mathrm{ml}$ ). Sample solution was prepared by taking $0.1 \mathrm{ml}$ of $L$. stoechas methanotic extract $(200 \mu \mathrm{g} / \mathrm{ml})$. To each test tube, 
FCR $(0.5 \mathrm{ml})$ and $35 \%$ sodium carbonate $(1 \mathrm{ml})$ were mixed and final volume was made $10 \mathrm{ml}$ by adding distilled water. All the test tubes were shaken and kept at room temperature for half an hour and absorbance was read at $725 \mathrm{~nm}$ against a blank. Tannic acid calibration curve was drawn and total tannin contents of extract were expressed as mg tannic acid equivalent/g of extract (Polshettiwar et al., 2007).

\section{In vitro Antioxidant Activity DPPH Free Radical Scavenging Assay}

Antioxidant activity of $L$. stoechas methanolic extract was determined by using DPPH free radical scavenging assay developed by Blois (1958). Methanolic solution of DPPH $(1.0 \mathrm{mmol} / \mathrm{L})$ was prepared in volumetric flask, covered with aluminum foil and put into dark place after marking as reagent stock solution. Different solutions of plant extract and standard ascorbic acid (1 $\mathrm{ml}$ each) having concentrations (20, 40, 60, 80,100 , and $200 \mu \mathrm{g} / \mathrm{ml}$ ) were prepared separately in test tubes. Then, $2 \mathrm{ml}$ of reagent stock solution was put into each test tube, mixed on vortex and incubated for $30 \mathrm{~min}$, at $37^{\circ} \mathrm{C}$ in dark place. Blank solution was prepared in the same way having all the ingredients except test substances. The absorbance of blank and all test solutions was measured at $517 \mathrm{~nm}$ by using UV-Vis spectrophotometer. Percentage scavenging activity was determined by applying following formula:

\section{Radical scavenging $(\%)=$ Absorbance of Blank - Absorbance of Sample $\times 100 /$ Absorbance of Blank}

\section{Experimental Animals}

Male Swiss albino mice (20-25 g) were used in this study. They were housed in polycarbonate cages in animal house of Punjab University College of Pharmacy, University of the Punjab, Lahore. Special permission regarding animal ethics was obtained from research ethics committee of the institute with diary number AEC/PUCP/1072. The animals were provided with standard living conditions (temperature; $25 \pm 2{ }^{\circ} \mathrm{C}$, humidity; $50 \pm 5 \%$ and 12:12 light/dark span) and had free access of standard pellet diet and water ad libitum. Animals were acclimatized in lab and were trained for all three paradigms for 1 week before the start of behavioral experiments.

\section{Study Design}

Mice were divided into seven groups $(n=6)$ and were treated accordingly as shown in Table $\mathbf{1 .}$

\section{Behavioral Studies}

All behavioral experiments were performed in sound proof room in dim day light and mice were put apart to avoid acoustic and visual disturbances. Observations were recorded by using digital camera connected with computer monitor.

\section{Elevated Plus Maze}

Elevated plus maze (EPM) is considered the most reliable paradigm for evaluation of memory (Pahaye et al., 2017), which was made up of two poly acrylic sheets joined together in shape of plus sign in such a way that it had two open arms $(16 \mathrm{~cm} \times 5 \mathrm{~cm})$, two closed arms $(16 \mathrm{~cm} \times 5 \mathrm{~cm} \times 12 \mathrm{~cm})$ and a central platform $(5 \mathrm{~cm} \times 5 \mathrm{~cm})$. Apparatus was put on a wooden stand elevated $25 \mathrm{~cm}$ from floor (Kulkarni et al., 2011). Mouse was put on open arm by facing it away from central platform and time taken (s) by it to move in any of closed arm with all its four legs was recorded and then returned into its home cage. Each animal was given maximum $90 \mathrm{~s}$ to explore the apparatus. If it failed to find closed arms for given time then it was pushed into closed arm with its tale and latency time was marked as $90 \mathrm{~s}$ for that animal. Initial transfer latency was observed after 45 min of administration of scopolamine and retention of latency was recorded after $24 \mathrm{~h}$ of administration of scopolamine and inflexion ratio (IR) (Kasture et al., 2007) was calculated by following formula; $\mathrm{IR}=\left(\mathrm{L}_{0}-\mathrm{L}_{1}\right) / \mathrm{L}_{0}$ where, $\mathrm{IR}=$ inflexion ratio, $\mathrm{L}_{0}$ is initial transfer latency $(\mathrm{s})$ and $\mathrm{L}_{1}$ is retention transfer latency in seconds.

\section{Light and Dark Test Apparatus}

This paradigm is used for the evaluation of learning tasks as proposed by Barry et al. (1987), which is based upon the principle that rodents prefer to live in dark compartment. Apparatus was made up of poly acrylic sheets and had two compartments; larger $(30 \mathrm{~cm} \times 30 \mathrm{~cm} \times 35 \mathrm{~cm})$ transparent chamber separated from smaller chamber $(20 \mathrm{~cm} \times 30 \mathrm{~cm} \times 35 \mathrm{~cm})$ which was colored black to make it dark. Both chambers had small opening $(5 \mathrm{~cm} \times 5 \mathrm{~cm})$ in the middle bottom of separating wall for entrance. The floor of both chambers was marked by lines each $1 \mathrm{~mm}$ apart. Mouse was put in the light chamber and was observed carefully for $5 \mathrm{~min}$ to record the time spent in each chamber. According to study designs, the animals were given doses and observations were recorded by using light and dark test apparatus for 2 days after the completion of last dose.

\section{Hole Board Test}

For assessment of learning behavior, hole board test paradigm (Durcan and Lister, 1988) was used with minor modification (Hossain and Uma Devi, 2001) which was composed of rectangular shaped, poly acrylic box $(35 \mathrm{~cm} \times 45 \mathrm{~cm} \times 45 \mathrm{~cm})$. Black colored sheet contained sixteen holes $(2 \mathrm{~cm}$ diameter and at equal distance) was supported on corners, $5 \mathrm{~cm}$ above the bottom of box. The animal was put in the middle of box and observed for $5 \mathrm{~min}$ to record number of hole pokings. Animals were given doses according to the protocols of study design and then observations were recorded for two consecutive days.

\section{Biochemical Assessment}

After performance of behavioral tests the animals were given anesthesia by using chloroform and were decapitated to isolate brains. Each brain was rinsed with ice cold normal saline after weighing it and $20 \mathrm{mg}$ of it was homogenized in $1 \mathrm{ml}$ ice cold phosphate buffer ( $\mathrm{pH}$ 7.4.) by using tissue homogenizer. To separate out the nuclear debris, the homogenized mixture was then centrifuged for $5 \mathrm{~min}$ at $69.40 \times g$ by keeping the temperature $4^{\circ} \mathrm{C}$. Supernatant was again centrifuged for $20 \mathrm{~min}$ at $1,0845 \times g$ at the same temperature and supernatant thus obtained was used for biochemical tests (Rajesh et al., 2017). 
TABLE 1 | Study design.

\begin{tabular}{|c|c|c|}
\hline No. & Treatment from day 1 to day 7 & Treatment on day 7 th, $45 \mathrm{~min}$ after administration of the last dose \\
\hline G-I (Normal Control) & Normal saline 10 ml/kg/p.o. & - \\
\hline G-II (Amnesic Control) & 5\% CMC 10 ml/kg/p.o. & Scopolamine (10 mg/kg/p.o.) \\
\hline G-III (Standard Control-A) & Piracetam 200 mg/kg/p.o. & - \\
\hline G-IV (Standard Control-B) & Piracetam 200 mg/kg/p.o. & Scopolamine (10 mg/kg/p.o.) \\
\hline G-V (Experimental Control-I) & meL.s 200 mg/kg/p.o. & Scopolamine (10 mg/kg/p.o.) \\
\hline G-VI (Experimental Control-II) & mel.s 400 mg/kg/p.o. & Scopolamine (10 mg/kg/p.o.) \\
\hline G-VII (Experimental Control-III) & meL.s 800 mg/kg/p.o. & Scopolamine (10 mg/kg/p.o.) \\
\hline
\end{tabular}

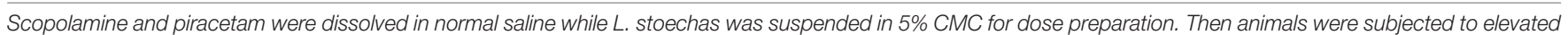
plus maze (EPM), light and dark test apparatus and hole board test apparatus for behavioral assessment.

\section{Acetylcholinesterase (AChE) Activity}

Ellman's method was used for estimation of AChE level for which $0.4 \mathrm{ml}$ of supernatant was taken in cuvette already contained $2.6 \mathrm{ml}$ of phosphate buffer $(0.1 \mathrm{M} / \mathrm{L}, \mathrm{pH} ; 8)$ and $100 \mu \mathrm{L}$ of 5,5'-dithiobis-2-nitrobenzoic acid. The reaction mixture was thoroughly mixed and absorbance was recorded several times by using UV-Vis spectrophotometer at $412 \mathrm{~nm}$. Then $20 \mu \mathrm{L}$ of acetyl thiocholine iodide was added as substrate in the reaction mixture and variations in absorbance were recorded five times at 2 min interval and finally change in absorbance per min was found (Ellman et al., 1961). Then following formula was applied to find level of AChE;

$$
R=5.74 \times 10^{-4} \times A / C O
$$

$R$ is the rate (moles) of substrate hydrolyzed $/ \mathrm{min} / \mathrm{g}$ of brain tissue, $A$ is change in absorbance per min, and $C O$ is original concentration $(20 \mathrm{mg} / \mathrm{ml})$ of tissue.

\section{Assessment of Malondialdehyde (MDA) Level in Brain} The level of malondialdehyde (MDA) was determined by mixing $100 \mu \mathrm{L}$ of brain homogenates with $1.5 \mathrm{ml}$ of TBA $(0.8 \% \mathrm{w} / \mathrm{v})$, $1.5 \mathrm{ml}$ of acetic acid $(20 \% \mathrm{v} / \mathrm{v})$ and $200 \mu \mathrm{L}$ of sodium dodecyl sulfate $(8 \% \mathrm{w} / \mathrm{v})$. The reaction mixture was heated at $95^{\circ} \mathrm{C}$ for $1 \mathrm{~h}$ and then $5 \mathrm{~mL}$ of $n$-butanol was added to mixture after cooling it at room temperature. Mixture was centrifuged at $976 \times g$ for $10 \mathrm{~min}$ and organic layer formed at top was collected for which the absorbance was measured at $532 \mathrm{~nm}$ (Xian et al., 2011). The following formula was used to find the concentration of MDA in brain.

$$
\operatorname{MDA}(\mu \mathrm{M})=A(\text { sample }) \times D F / I \times \varepsilon
$$

$I=$ light path $=1 \mathrm{~cm}, \varepsilon=$ molar absorptivity $=1.56 \times 10^{5}$ $\mathrm{M}^{-10} \mathrm{~cm}^{-1}$ and $\mathrm{DF}=$ dilution factor $=21$.

\section{Measurement of Superoxide Dismutase (SOD) Level}

The level of SOD was found by diluting brain homogenate $(0.5 \mathrm{ml})$ with distilled water $(1 \mathrm{ml})$ which was then added chilled ethanol $(2.5 \mathrm{ml})$ and chloroform $(1.5 \mathrm{ml})$. Mixture was well shaken and centrifuged for $1 \mathrm{~min}$ at $4^{\circ} \mathrm{C}$. The supernatant was mixed with $1.2 \mathrm{ml}$ of $(0.025 \mathrm{M}, \mathrm{pH} 8.4)$ sodium pyrophosphate buffer, $0.3 \mathrm{ml}$ of $30 \mu \mathrm{M}$ NBT, $0.1 \mathrm{ml}$ of $186 \mu \mathrm{M}$ PMS, $0.2 \mathrm{ml}$ of 780 $\mu \mathrm{M}$ of reduced nicotinamide adenine dinucleotide (NADH) and $3 \mathrm{ml}$ of distilled water. The reaction mixture was incubated for $90 \mathrm{~s}$ at $30^{\circ} \mathrm{C}$ and the reaction which was initiated by addition of $\mathrm{NADH}$ was stopped by subsequent addition of glacial acetic acid $(1 \mathrm{ml})$. Reaction mixture was vigorously stirred and then mixed with $n$-butanol by gentle shaking. Butanol layer was separated out and absorbance was measured at $560 \mathrm{~nm}$ against butanol blank. Amount of SOD was expressed as unit/mg of protein (Kakkar et al., 1984).

\section{Measurement of Catalase (CAT) Activity}

Catalase (CAT) activity was found by mixing tissue homogenate $(0.1 \mathrm{ml})$ with $1.0 \mathrm{ml}$ of $0.01 \mathrm{M}$ phosphate buffer $(\mathrm{pH} 7.0)$ and $0.4 \mathrm{ml}$ of $2 \mathrm{M} \mathrm{H}_{2} \mathrm{O}_{2}$. Then $2 \mathrm{ml}$ of dichromate acetic acid reagent composed of $5 \%$ potassium dichromate and glacial acetic acid in ratio 1:3 was added in reaction mixture to stop the reaction and absorbance was taken at $620 \mathrm{~nm}$. CAT activity was expressed as $\mu \mathrm{M}$ of $\mathrm{H}_{2} \mathrm{O}_{2}$ decomposed/min/mg of protein (Sinha, 1972).

\section{Determination of Glutathione (GSH) Activity}

Brain homogenate $(0.4 \mathrm{ml})$ was mixed with $0.4 \mathrm{ml}$ of $20 \%$ TCA and mixture was centrifuged at $10,000 \times g$ for $20 \mathrm{~min}$ at $4^{\circ} \mathrm{C}$. The supernatant $(0.25 \mathrm{ml})$ was then added $0.6 \mathrm{M} \mathrm{DTNB}(2 \mathrm{ml})$ and phosphate buffer $(0.2 \mathrm{M}, \mathrm{pH} 8.0)$ was used to make final volume of $3 \mathrm{ml}$. Then absorbance was read at $412 \mathrm{~nm}$ against blank. Standard calibration curve was made by using different concentrations of glutathione (GSH) $(10-50 \mu \mathrm{M})$ by dissolving in TCA $(0.4 \mathrm{ml})$ and concentration of GSH in brain was expressed as $\mu \mathrm{M} / \mathrm{mg}$ of tissue protein (Moron et al., 1979).

\section{Statistical Analysis}

The data were expressed as mean \pm SEM. Student's $t$-test analysis was applied on data with paired comparisons and multiple comparisons were made by ANOVA followed by Dunnett's test by using GraphPad Prism software version 7. Value of $P<0.05$ was marked as significant.

\section{RESULTS}

\section{Percentage Yield of Plant Extract}

Simple methanolic extraction of $L$. stoechas gave $220 \mathrm{~g}$ semi solid extract per 1,000 $\mathrm{g}$ of dried powdered plant material and hence $\%$ age yield was $22 \% \mathrm{w} / \mathrm{w}$. 


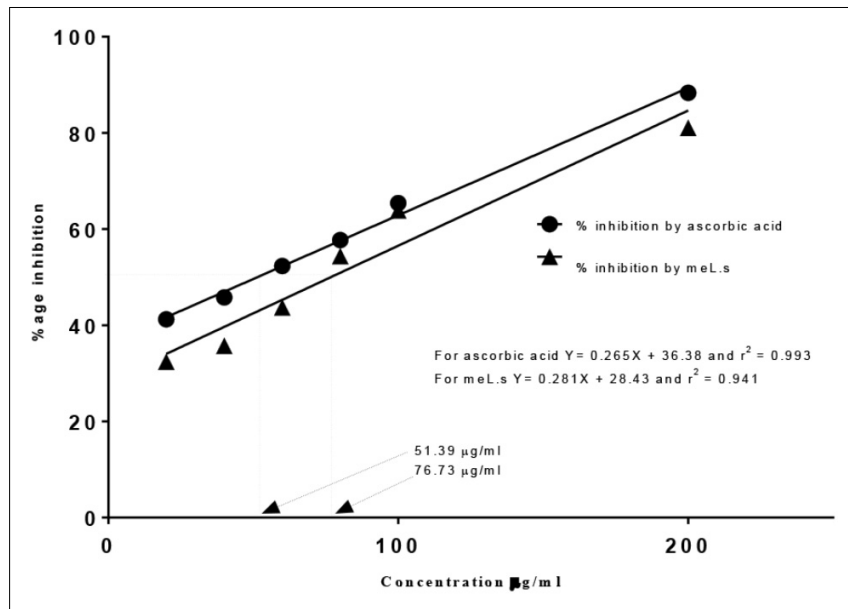

FIGURE 1 | Free radical scavenging activity of meL.s and standard (ascorbic acid) along with their $\mathrm{IC}_{50}$ values.

\section{Phytochemical Constituents}

Qualitative phytochemical analysis of methanolic extract of L. stoechas (meL.s) showed the presence of following constituents as expressed in Table 2.

\section{Quantitative Analysis of Bioactive Constituents of Methanolic Extract of L. stoechas (meL.s)}

Total phenolic, flavonoid, and tannin contents in methanolic extract of $L$. stoechas (meL.s) were found to be $285.91 \pm 0.75 \mathrm{mg}$ of GAE/g of extract, $134.06 \pm 0.63 \mathrm{mg}$ of RE/g of extract and $149.60 \pm 0.93 \mathrm{mg}$ of TAE/g of dried plant extract, respectively.

TABLE 2 | Phytochemical analysis of methanolic extract of Lavandula stoechas (meL.s).

\begin{tabular}{lllc}
\hline No. & Phytochemical constituents & Tests & Presence \\
\hline 1 & Proteins & Ninhydrin test & ++ \\
2 & Carbohydrates & Molish test & + \\
3 & Alkaloids & Hagers's test & ++ \\
& & Wagner's test & ++ \\
& & Dragendroff's test & + \\
& & Mayer's test & ++ \\
4 & Glycosides & Killer-Kiliani test & + \\
5 & Flavonoids & Alkaline reagent test & + \\
6 & Steroids & Ring test & + \\
7 & Terpenoids & & + \\
8 & Saponins & Foam test & + \\
9 & Tannins & Ferric chloride test & + \\
10 & Phenols & FC method & ++ \\
11 & Quinones & & - \\
12 & Phytosterol & Liebermann-Burchard test & ++ \\
13 & Terpenes & Salkowski test & + \\
14 & Fixed oils & Spot test & - \\
\hline
\end{tabular}

+, present; ++, highly present; and -, absent.

\section{Free Radical Scavenging Activity}

Free radical scavenging activity found by DPPH assay indicated that $\mathrm{IC}_{50}$ value for methanolic extract of $L$. stoechas (meL.s) was $76.73 \mu \mathrm{g} / \mathrm{ml}$ and that of standard ascorbic acid it was $51.39 \mu \mathrm{g} / \mathrm{ml}$ as shown in Figure 1. Moreover, considering yield of extract, it was calculated that $1 \mathrm{mg}$ of crude plant powder was equal to $220 \mu \mathrm{g}$ of meL.s.

\section{Effect of Methanolic Extract of L. stoechas (meL.s) on Transfer Latency} (TL) in EPM Paradigm

Initial transfer latency (ITL) was recorded on day 7th of treatment (45 min after administration of scopolamine) which reflected the learning behavior of animal while, retention transfer latency (RTL) was noted after $24 \mathrm{~h}$ of administration of last dose which exhibited retention of learning tasks. Inflexion ratio was calculated from transfer latencies which indicated the improvement of memories in mice. It was observed that ITL and RTL values of Group-II (amnesic control) were significantly $(P<0.001)$ high from values of Group-I (normal control) which clearly indicated the loss of memory in amnesic group. Standard control, meL.s $400 \mathrm{mg} / \mathrm{kg} /$ p.o. and meL.s $800 \mathrm{mg} / \mathrm{kg} /$ p.o. significantly $(P<0.001)$ reduced the time spent by animal in open arms as compared to Group-II which indicated improvement of memory as shown in Figure 2A. Similarly, RTL values of Groups-III to VII were significantly less $(P<0.001)$ than values of Group-II which indicated the retention of memory by animals as shown in Figure 2B. Inflexion ratios of GroupIV and VII were $0.44 \pm 0.04$ and $0.40 \pm 0.03$, respectively, which were significantly $(p<0.001)$ higher than amnesic group having IR $=-0.20 \pm 0.03$. While Group V and VI have $\mathrm{IR}=0.11 \pm 0.05$ and $0.17 \pm 0.03$, respectively, as shown in Figure 2C.

\section{Effect of Methanolic Extract of L. stoechas (meL.s) on Time Spent in Light and Dark Compartment}

Effect of meL.s on time spent in both compartments of light and dark paradigm is shown in Figure 3. Animals in GroupI spent less time in light compartment and remained most of time in dark compartment. Time spent by animals in light compartment was significantly increased $(P<0.001)$ in Group-II as compared to Group-I animals. Similarly, animals in Groups III-VII spent most of the time in dark arena both on first and second day which indicated that they significantly $(P<0.001)$ improved memory as compared to amnesic group.

\section{Effect of Methanolic Extract of L. stoechas (meL.s) on Number of Hole Pokings in Hole Board Paradigm}

It has been observed that no of hole pokings by mice in amnesic group was significantly $(P<0.001)$ reduced as compared to normal control group which indicated induction of amnesia. However, Groups-IV and VII significantly $(P<0.001)$ increased 
A

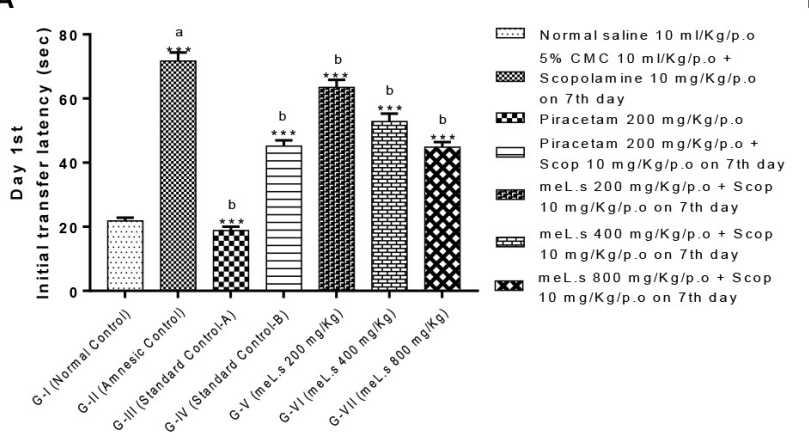

B

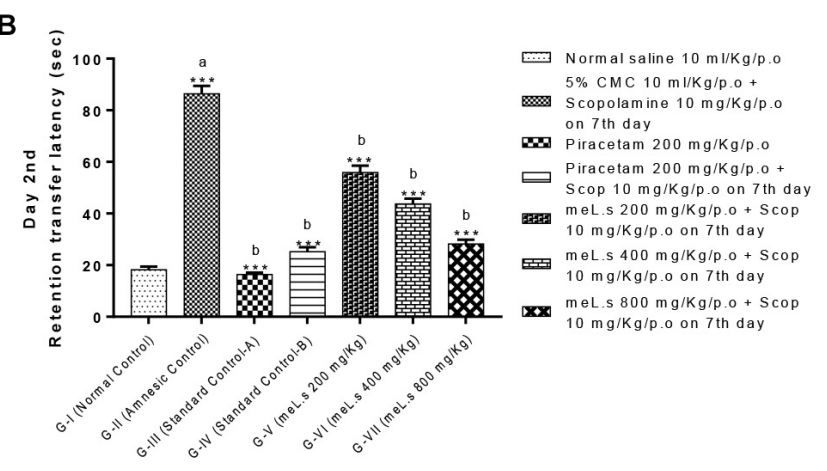

C

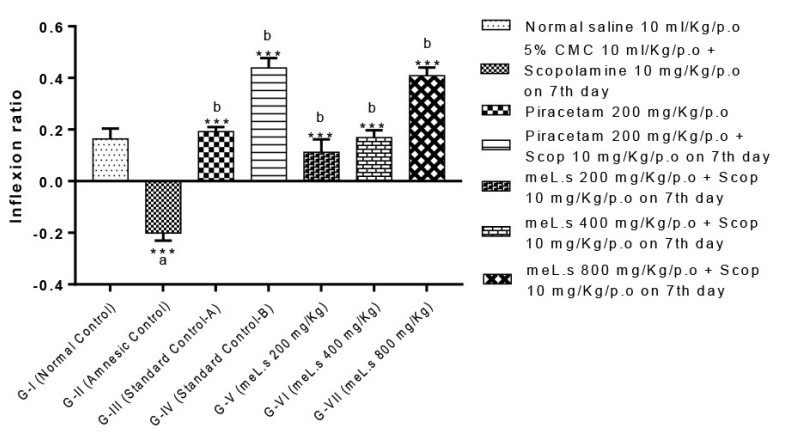

FIGURE 2 | Effect of meL.s on (A) initial transfer latency, (B) retention transfer latency, and (C) Inflexion ratio in elevated plus maze paradigm. All values were expressed as mean \pm SEM with $n=6$ per group. One-way ANOVA followed by Dunnett's test was applied on data set and G-II was compared with G-I (presented by sign "a" on bar) while other groups (G-III to G-VII) were compared with G-II (presented by sign "b" on bars). Value of $P \geq 0.05$ was shown by marking "ns" while $P$-values $\leq 0.05, \leq 0.01$, and $\leq 0.001$ were expressed as *, ${ }^{* *}$, and ${ }^{* * *}$, respectively.

no of hole pokings as compared to Group-II. Groups V-VI produced non-significant changes in hole pokings both at day 1st and 2 nd. All details are shown in Figure $\mathbf{4}$ which indicated that meL.s $800 \mathrm{mg} / \mathrm{kg} /$ p.o. was more effective than both of its lower doses.

\section{Effect of Methanolic Extract of L. stoechas (meL.s) on Concentration of Acetylcholinesterase (AChE) in Mice Brain}

Group-II animals significantly $(P<0.001)$ increased the level of AChE as compared to normal control animals. However, pretreatment of animals with standard drug piracetam and plant extract in different doses showed marked reduction in level of AChE. Among treatment groups meL.s $800 \mathrm{mg} / \mathrm{kg} /$ p.o. caused maximum reduction in the level of $\mathrm{AChE}$ which was significantly $(P<0.001)$ less than the amnesic group. The details are given in Figure 5A.

\section{Effect of Methanolic Extract of L. stoechas (meL.s) on MDA, SOD, CAT, and GSH Levels in Mice Brain}

It was observed that administration of scopolamine to Group-II animals significantly $(P<0.001)$ increased the level of MDA in brain while SOD, CAT, and GSH levels were declined in comparison to normal control group. A significant $(P<0.001)$ reduction in MDA and elevation in SOD, CAT, and GSH level was observed in animals treated with standard drug piracetam in comparison to Group-II animals. Pretreatment of animals with meL.s $800 \mathrm{mg} / \mathrm{kg} / \mathrm{p}$.o. significantly decreased the MDA contents of mice brain while SOD and GSH were significantly $(P<0.001)$ improved as compared to groups treated with same extract in low doses but CAT level was non-significantly improved by it. From Figure 5 it is clear that meL.s $200 \mathrm{mg} / \mathrm{kg} /$ p.o. did not increase the level of SOD, GSH, and CAT while meL.s $400 \mathrm{mg} / \mathrm{kg} /$ p.o. produced less significant $(P<0.05)$ results as compared to amnesic group. Similarly, $800 \mathrm{mg} / \mathrm{kg} / \mathrm{p}$. .o. nonsignificantly improved the CAT level. The detailed results of biochemical markers are shown in Figures 5B-E.

\section{DISCUSSION}

Neurodegeneration in the brain, initially results into loss of short term memory (Burns and liffe, 2009) which progresses toward disorientation speech, mood swing, social withdrawals, altered behavioral patterns and ultimately death (Todd et al., 2013) due to loss of cognition over a time span of a decade or more (Alzheimer's Association Report, 2017). Cholinergic hypothesis best narrates the pathogenesis of dementia by loss of 

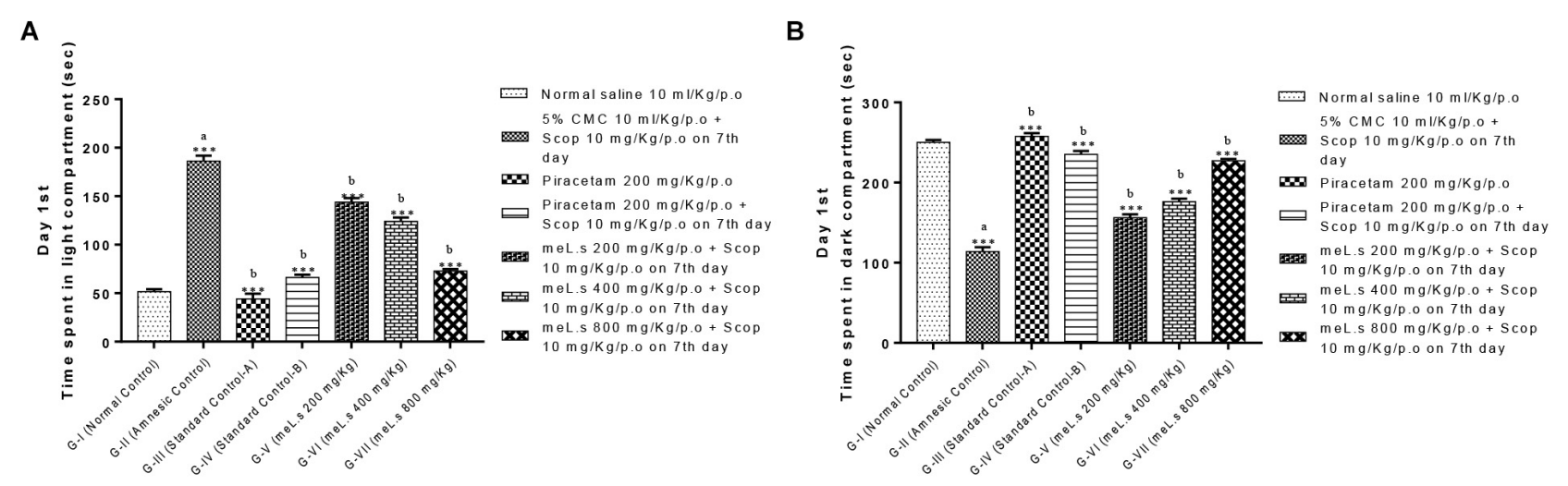

C

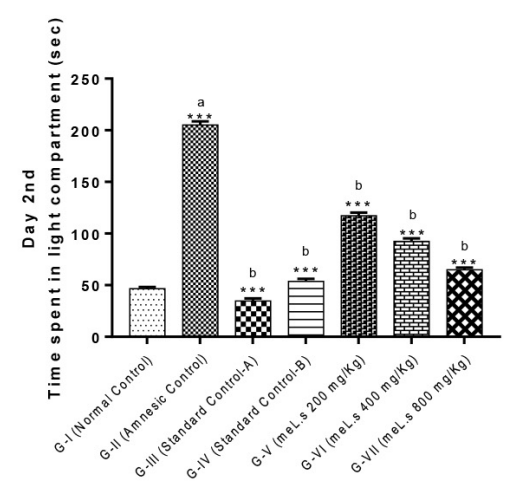

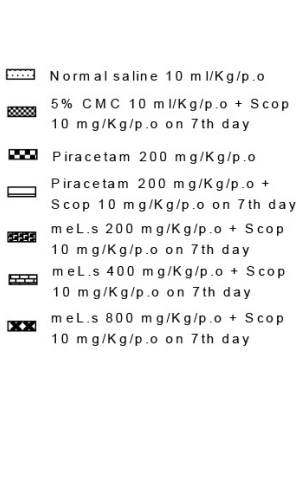

D

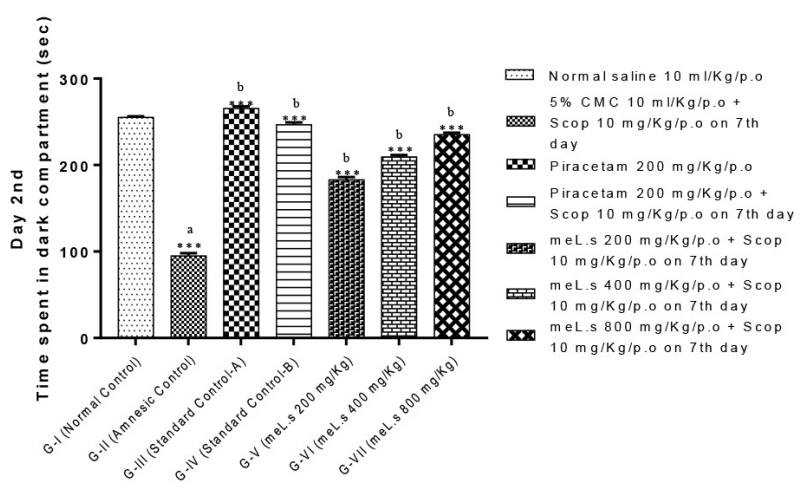

FIGURE 3 | Effect of meL.s on (A) time spent (s) in light compartment on day 1st, (B) time spent (s) in dark compartment on day 1st, (C) time spent (s) in light compartment on day $2 n d$, and (D) time spent (s) in dark compartment on day 2nd. All values were expressed as mean \pm SEM with $n=6$ per group. One-way ANOVA followed by Dunnett's test was applied on data set and G-II was compared with G-I (presented by sign "a" on bar) while other groups (G-III to G-VII) were compared with G-II (presented by sign "b" on bars). Value of $P \geq 0.05$ was shown by marking "ns" while $P$-values $\leq 0.05, \leq 0.01$, and $\leq 0.001$ were expressed as *, **, and ***, respectively.
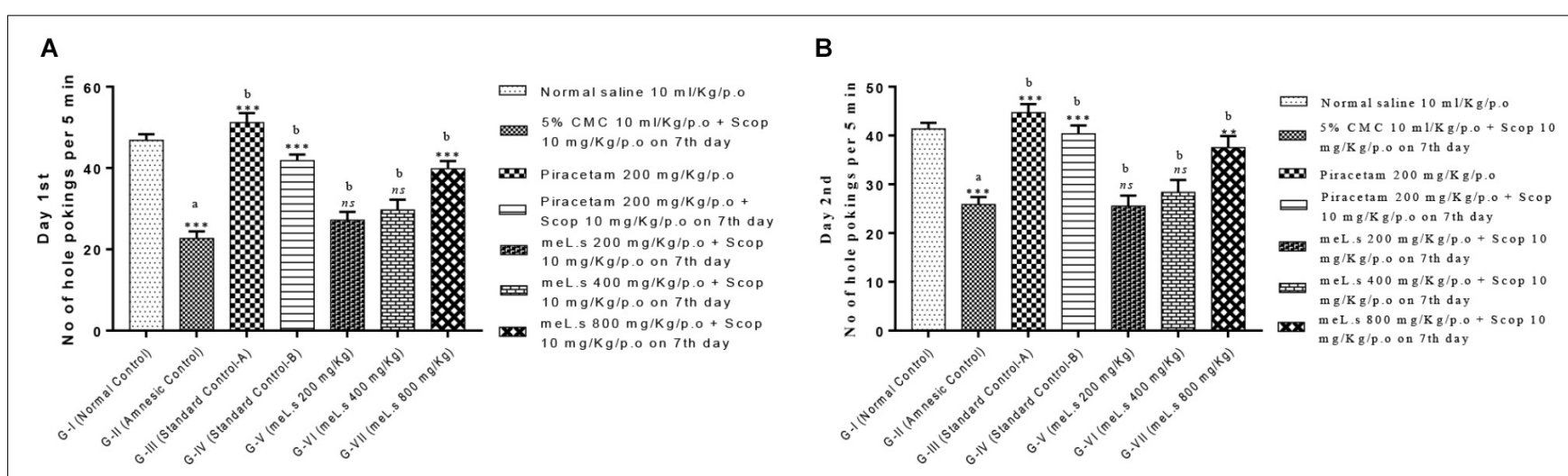

FIGURE 4 | Effect of meL.s on (A) no of hole pokings by mice on day 1st and (B) no of hole pokings by mice on day 2nd. All values were expressed as mean \pm SEM with $n=6$ per group. One-way ANOVA followed by Dunnett's test was applied on data set and G-II was compared with G-I (presented by sign "a" on bar) while other groups (G-III to G-VII) were compared with G-II (presented by sign "b" on bars). Value of $P \geq 0.05$ was shown by marking "ns" while $P$-values $\leq 0.05$, $\leq 0.01$, and $\leq 0.001$ were expressed as $*,{ }^{* *}$, and ${ }^{* * *}$, respectively.

cholinergic innervations in frontal cortex, cingulated gyrus and hippocampus of the brain (Wenk, 2003). Similarly, accumulation of $\beta$-amyloid protein and extra neuronal plaque formation due to severe oxidative damage (Da Silva Filho et al., 2017;
Omar et al., 2017) are main causes of memory loss (Hardy and Higgins, 1992; Wilson and Binder, 1997; Da Silva Filho et al., 2017). It has been roughly estimated that oxidative stress is responsible for pathogenesis of more than hundred 


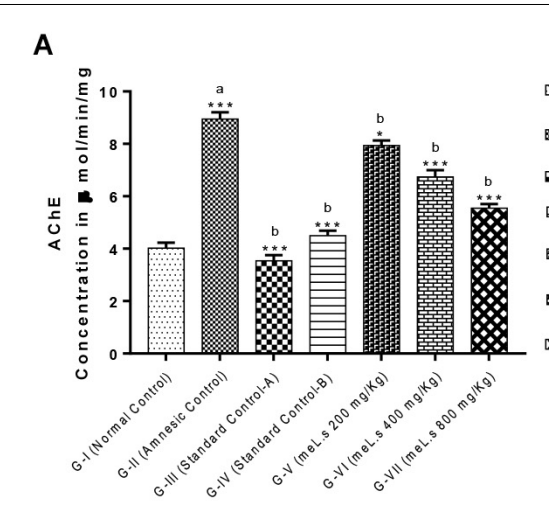

C

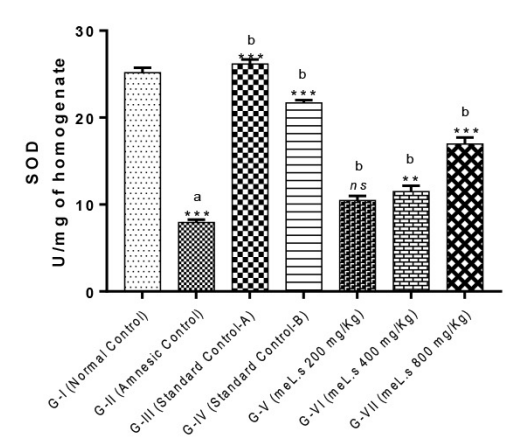

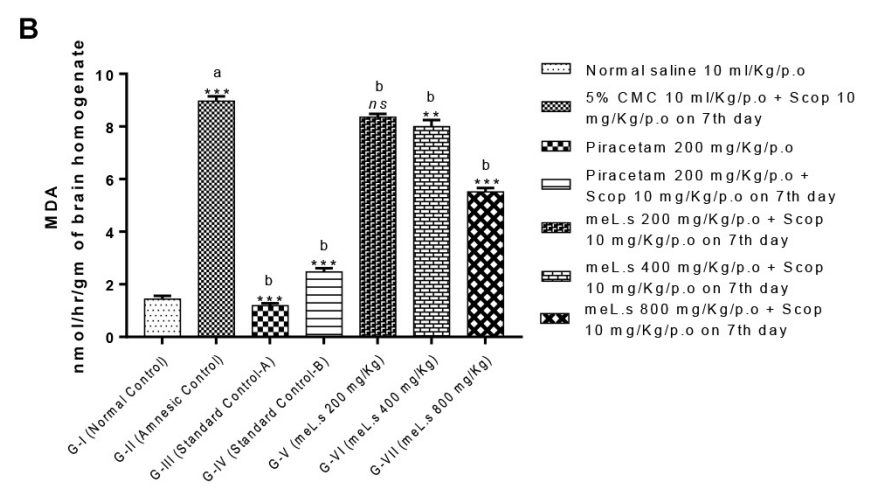

D
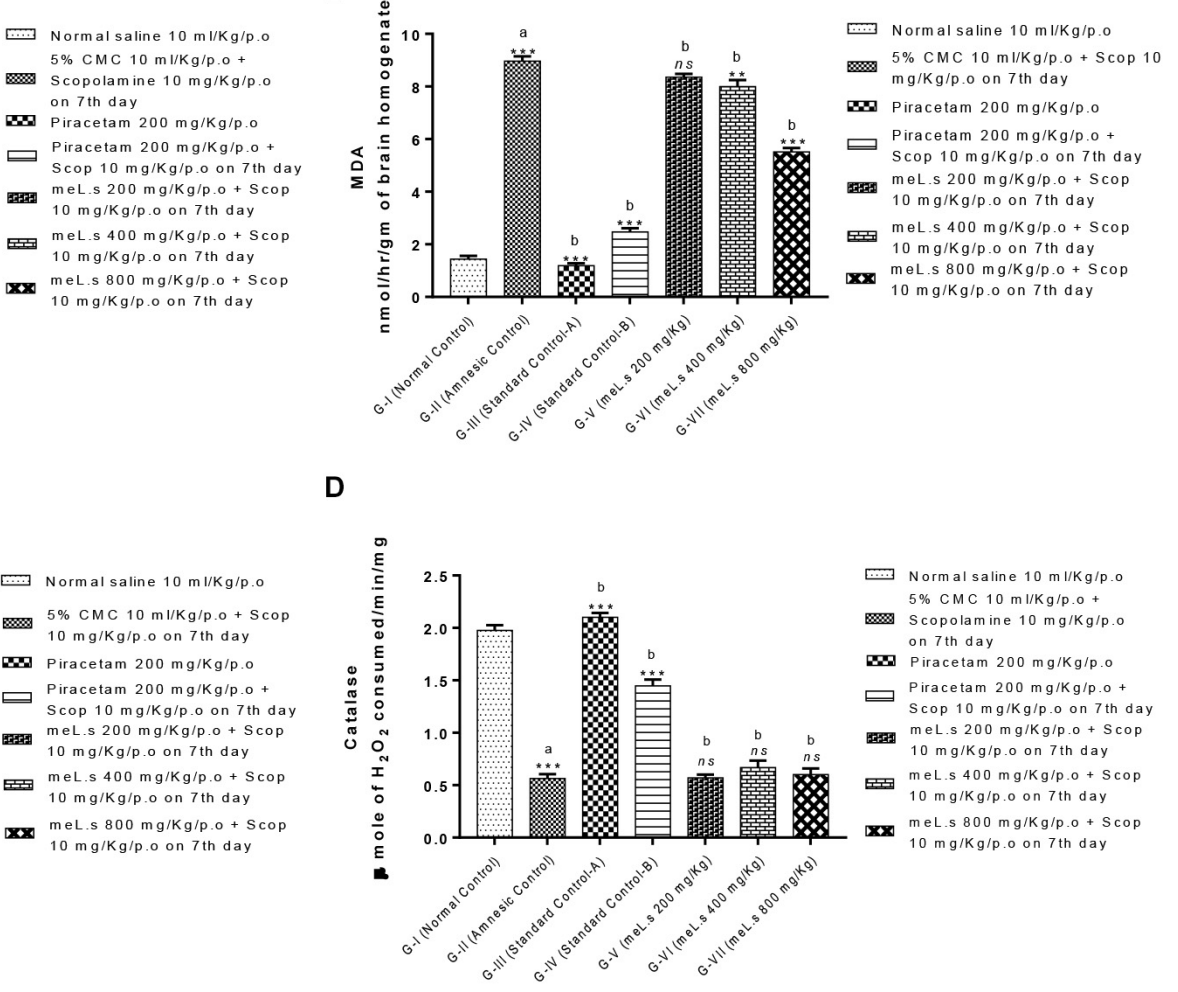

mel.s $800 \mathrm{mg} / \mathrm{Kg} / \mathrm{p} . \mathrm{o}+\mathrm{Sco}$

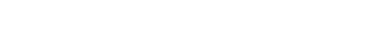

E

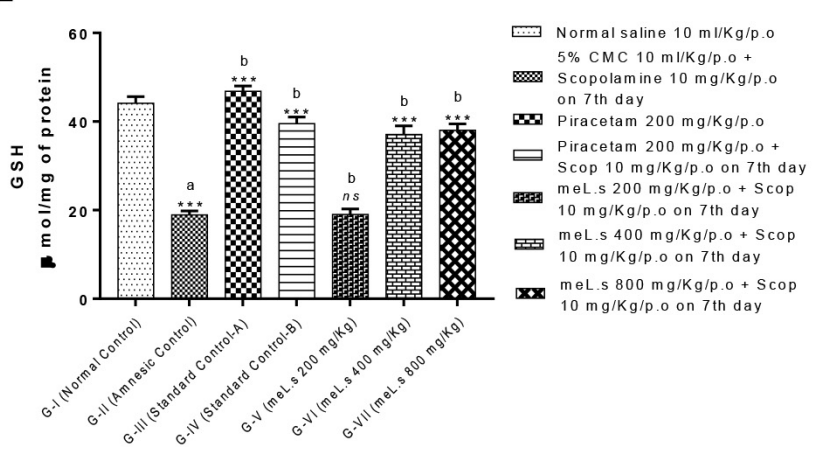

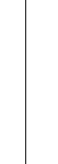


in management of dementia in traditional medicinal practice (Nadkarni, 1996), this study was planned to explore its active constituents responsible for anti amnesic activity. The current research paper is initial finding of this series. In this investigation EPM, light and dark test and hole board paradigms were used for behavioral observations to reach the conclusion as proposed by Hossain and Uma Devi (2001).

Behavioral studies using EPM paradigm indicated that methanolic extract of L. stoechas showed dose dependent decrease in transfer latencies (decrease latency means improvement of learning tasks) and increased the inflexion ratio (a hallmark of improvement in retaining learned tasks) in comparison to amnesic group. Currently, EMP is widely employed paradigm in assessment of memory and learning tasks in rodents (Barez-Lopez et al., 2017) and considered reliable method of assessment of memory (Chauhan and Chaudhary, 2012). Pre treatment of animals with plant extract prior to administration of scopolamine prevented the impairment of learning and retaining capabilities which indicates the effectiveness of L. stoechas in memory build up. Similarly, findings of light dark paradigm illustrate that extract treated animals retained their learned ability of spending most of time in dark area while G-II animals (scopolamine treated) lost their memory to go into dark compartment and hence lived most of the time in light area. This supported the effectiveness of memory enhancing effect of plant along with efficiency of this paradigm in evaluation of memory tasks (Barry et al., 1987). Hole board paradigm used for behavioral analysis was based upon concept that increased no of hole pokings by mice retained their exploration behavior while scopolamine impaired their memory of exploration (Durcan and Lister, 1988). Thus it was observed that standard drug piracetam and plant extract in high doses increased the no of hole pokings by mice as compared to scopolamine treated mice. Investigation of memory enhancing effect of L. stoechas through behavioral analysis was further supported by evaluation of biochemical markers in brain homogenates of mice.

Acetylcholine is degraded by AChE at the level of synaptic cleft which diminishes cholinergic transmission (Ballard et al., 2005). An agent enhancing the level of AChE will impair memory by reducing acetylcholine levels as scopolamine did in amnesic group. In contrary, standard drug piracetam and methanolic plant extract $(800 \mathrm{mg} / \mathrm{kg} /$ p.o. $)$ retained the memory of mice as observed by behavioral studies by significantly $(P<0.001)$ lowering the level of AChE in brain (Figure 5A). Presence of alkaloids and flavonoids $(134.06 \pm 0.63 \mathrm{mg} / \mathrm{g})$ in L. stoechas supported the acetyl cholinesterase activity of plant extract (Ma and Gang, 2008). Moreover, anti-oxidant studies suggested that plant extract also prevented the brain from oxidative stress (Pratico, 2008) by raising the level of SOD, GSH and CAT as shown in Figures 5B-E. Brain is highly susceptible to be damaged by oxidizing agents because high oxygen consumption, low GSH levels and polyunsaturated fat deposition in brain damage the neurons in brain (Mamelak, 2007; Sonnen et al., 2008). Exposure of brain with hydrogen peroxide results into production of several enzymes like $\beta$-secretase and $\gamma$-secretase which cleave amyloid precursor protein into amyloid $\beta$-peptide. Accumulation of amyloid $\beta$-peptide in brain is hallmark of loss of memory (Butterfield, 2002; Tong et al., 2005). Similarly, lipid peroxidation in brain elevates the level of MDA in brain which suggested loss of memory due to oxidative stress (Sultana et al., 2013). Thus, antioxidants protect the brain from this damage by scavenging free radicals (Omar et al., 2017). In vitro antioxidant activity of plant extract as observed by DPPH method ensured that it exhibited free radical scavenging activity (Figure 1). Total phenols were estimated to be $85.91 \mathrm{mg} / \mathrm{g}$ plant extract which were supposed to scavenge free oxygen, hydrogen peroxide, superoxide, and hydroxyl radicals (Pereira et al., 2009) and prevented the brain from oxidative stress. Scopolamine damaged the memory by depleting natural antioxidants present in brain, i.e., SOD, GSH, and CAT (El-Sherbiny et al., 2003) but current findings clearly declared $L$. stoechas a strong anti oxidant which reduced the level of MDA and increased SOD, GSH, and CAT levels in mice brain. Elevation of SOD and CAT prevented the damage caused by superoxide radicals and $\mathrm{H}_{2} \mathrm{O}_{2}$ respectively (Bhattacharjee et al., 2015) while GSH scavenged free radicals in brain proteins (Farombi et al., 2000). Based upon concluding results of current study, it is increasingly evidenced that antioxidant supplementation improves cognition on one hand and slows down the progression of dementia on other side.

\section{CONCLUSION}

It is concluded that dementia is linked with oxidative stress and loss of cholinergic innervations in brain neurons. L. stoechas could prove helpful in attenuation of dementia as it reduces oxidative burden of neurons and decreases neuro-degradation of cholinergic transmission in mice brain. This research is first finding of the series and further studies are in progress in our lab to reach a bio molecule of $L$. stoechas actually responsible for anti amnesic activity along with an appropriate mechanism of action.

\section{AUTHOR CONTRIBUTIONS}

AM conducted the experimental work. MA and RA proposed the study design, supervised the experimental work, and guided in writing manuscript.

\section{ACKNOWLEDGMENTS}

Special vote of thanks to Prof. Dr. Mobasher Ahmad Butt who not only supervised the work but provided the full technical and scientific support also to conduct the study smoothly. A bundle of gratitude to the management of Gulab Devi Institute of Pharmacy, Gulab Devi Educational Complex, Lahore and Punjab University College of Pharmacy, University of the Punjab, Lahore to facilitate the project. 


\section{REFERENCES}

Adams, M., Gmünder, F., and Hamburger, M. (2007). Plants traditionally used in age related brain disorders-a survey of ethnobotanical literature. J. Ethnopharmacol. 113, 363-381. doi: 10.1016/j.jep.2007.07.016

Alzheimer's Association Report. (2017). 2017 Alzheimer's disease facts and ures. Alzheimers Dement. 13, 325-373. doi: 10.1016/j.jalz.2017.02.001

Ballard, C. G., Greig, N. H., Guillozet-Bongaarts, A. L., Enz, A., and Darvesh, S. (2005). Cholinesterases: roles in the brain during health and disease. Curr. Alzheimer Res. 2, 307-318. doi: 10.2174/1567205054367838

Barez-Lopez, S., Montero-Pedrazuela, A., Bosch-García, D., Venero, C., and Guadaño-Ferraz, A. (2017). Increased anxiety and fear memory in adult mice lacking type 2 deiodinase. Psychoneuroendocrinology 84, 51-60. doi: 10.1016/j. psyneuen.2017.06.013

Barry, J. M., Costall, B., Kelly, M. E., and Naylor, R. J. (1987). Withdrawal syndrome following subchronic treatment with anxiolytic agents. Pharmacol. Biochem. Behav. 27, 239-245. doi: 10.1016/0091-3057(87)90565-X

Baxter, M. G., Bucci, D. J., Gorman, L. K., Wiley, R. G., and Gallagher, M. (2013). Selective immunotoxic lesions of basal forebrain cholinergic cells: effects on learning and memory in rats. Behav. Neurosci. 127, 619-627. doi: 10.1037/ a0033939

Bejar, C., Wang, R.-H., and Weinstock, M. (1999). Effect of rivastigmine on scopolamine-induced memory impairment in rats. Eur. J. Pharmacol. 383, 231-240. doi: 10.1016/S0014-2999(99)00643-3

Bhattacharjee, A., Shashidhara, S. C., and Saha, S. (2015). Nootropic activity of crataeva nurvala buch-ham against scopolamine induced cognitive impairment. EXCLI J. 14:335. doi: 10.17179/excli2014-541

Blois, M. S. (1958). Antioxidant determinations by the use of a stable free radical. Nature 181, 1199-1200. doi: 10.1038/1811199a0

Burns, A., and liffe, S. (2009). Alzheimer's disease. BMJ 338:b158. doi: 10.1136/bmj. b158

Butterfield, D. (2002). Amyloid $\beta$-peptide (1-42)-induced oxidative stress and neurotoxicity: implications for neurodegeneration in Alzheimer's disease brain. a review. Free Radic. Res. 36, 1307-1313. doi: 10.1080/1071576021000049890

Chauhan, B., and Chaudhary, A. K. (2012). Memory enhancing activity of methanolic extract of pterocarpus marsupium roxb. Phytopharmacology 2, 72-80.

Da Silva Filho, S. R. B., Barbosa, J. H. O., Rondinoni, C., dos Santos, A. C., Salmon, C. E. G., et al. (2017). Neuro-degeneration profile of Alzheimer's patients: a brain morphometry study. NeuroImage Clin. 15, 15-24. doi: 10.1016/j.nicl.2017. 04.001

Durcan, M. J., and Lister, R. G. (1988). Time course of ethanol's effects on locomotor activity, exploration and anxiety in mice. Psychopharmacology 96, 67-72. doi: 10.1007/BF02431535

Ellman, G. L., Courtney, K. D., Andres, V., and Featherstone, R. M. (1961). A new and rapid colorimetric determination of acetylcholinesterase activity. Biochem. Pharmacol. 7, 88-95. doi: 10.1016/0006-2952(61)90145-9

El-Sherbiny, D. A., Khalifa, A. E., Attia, A. S., and Eldenshary Eel, D. (2003). Hypericum perforatum extract demonstrates antioxidant properties against elevated rat brain oxidative status induced by amnestic dose of scopolamine. Pharmacol. Biochem. Behav. 76, 525-533. doi: 10.1016/j.pbb.2003.09.014

Farombi, E. O., Olowu, B. I., and Emerole, G. O. (2000). Effect of three structurally related antimalarial drugs on liver microsomal components and lipid peroxidation in rats. Comp. Biochem. Physiol. C Pharmacol. Toxicol. Endocrinol. 126, 217-224.

Francis, P. T., Palmer, A. M., Snape, M., and Wilcock, G. K. (1999). The cholinergic hypothesis of Alzheimer's disease: a review of progress. J. Neurol. Neurosurg. Psychiatry 66, 137-147. doi: 10.1136/jnnp.66.2.137

Gilani, A., Aziz, N., Khan, M., Shaheen, F., Jabeen, Q., Siddiqui, B., et al. (2000). Ethnopharmacological evaluation of the anticonvulsant, sedative and antispasmodic activities of Lavandula stoechas L. J. Ethnopharmacol. 71, 161167. doi: 10.1016/S0378-8741(99)00198-1

Giovannini, M., Casamenti, F., Bartolini, L., and Pepeu, G. (1997). The brain cholinergic system as a target of cognition enhancers. Behav. Brain Res. 83, 1-5. doi: 10.1016/S0166-4328(97)86038-X

Hake, A. M. (2001). Use of cholinesterase inhibitors for treatment of Alzheimer disease. Cleve. Clin. J. Med. 68, 608-609, 613-604, 616. doi: 10.3949/ccjm.68. 7.608
Hakeem, M., Siddiqui, M., and Khan, A. (1991). Antiepileptic activity of ustu khudoos in secondary epilepsy-a case report. Hamdard Med. 34, 33-39.

Hardy, J. A., and Higgins, G. A. (1992). Alzheimer's disease: the amyloid cascade hypothesis. Science 256:184. doi: 10.1126/science.1566067

Hossain, M., and Uma Devi, P. (2001). Effect of irradiation at the early foetal stage on adult brain function of mouse: learning and memory. Int. J. Radiat. Biol. 77, 581-585. doi: 10.1080/09553000110037394

Houghton, P. J., and Howes, M.-J. (2005). Natural products and derivatives affecting neurotransmission relevant to Alzheimer's and Parkinson's disease. Neurosignals 14, 6-22. doi: 10.1159/000085382

Howes, M. J. R., Perry, N. S., and Houghton, P. J. (2003). Plants with traditional uses and activities, relevant to the management of Alzheimer's disease and other cognitive disorders. Phytother. Res. 17, 1-18. doi: 10.1002/ptr.1280

Kakkar, P., Das, B., and Viswanathan, P. (1984). A modified spectrophotometric assay of superoxide dismutase. Indian J. Biochem. Biophys. 21, 130-132.

Kasture, S., Kasture, V., Joshua, A., Damodaran, A., and Amit, A. (2007). Nootropic activity of bacomind tm, an enriched phytochemical composition from Bacopa monnieri. J. Nat. Remedies 7, 166-173.

Kulkarni, P. D., Ghaisas, M. M., Chivatbe, N., and Sankpal, P. S. (2011). Memory enhancing activity of Cissampelos pariera in mice. Int. J. Pharm. Pharm. Sci. 3, 206-211.

Kumar, H., More, S. V., Han, S.-D., Choi, J.-Y., and Choi, D.-K. (2012). Promising therapeutics with natural bioactive compounds for improving learning and memory-a review of randomized trials. Molecules 17, 10503-10539. doi: 10. 3390/molecules170910503

Kumaran, A., and Karunakaran, R. J. (2007). In vitro antioxidant activities of methanol extracts of five Phyllanthus species from India. LWT Food Sci. Technol. 40, 344-352. doi: 10.1016/j.lwt.2005.09.011

Ma, X., and Gang, D. R. (2008). In vitro production of huperzine A, a promising drug candidate for Alzheimer's disease. Phytochemistry 69, 2022-2028. doi: $10.1016 /$ j.phytochem.2008.04.017

Mamelak, M. (2007). Alzheimer's disease, oxidative stress and gammahydroxybutyrate. Neurobiol. Aging 28, 1340-1360. doi: 10.1016/j. neurobiolaging.2006.06.008

McCord, J. M. (2000). The evolution of free radicals and oxidative stress. Am. J. Med. 108, 652-659. doi: 10.1016/S0002-9343(00)00412-5

Moron, M. S., Depierre, J. W., and Mannervik, B. (1979). Levels of glutathione, glutathione reductase and glutathione S-transferase activities in rat lung and liver. Biochim. Biophys. Acta Gen. Sub. 582, 67-78. doi: 10.1016/0304-4165(79) 90289-7

Mushtaq, A., Mahmood, A., and Jabeen, Q. (2013). Hepatoprotective action of a polyherbal aqueous ethanolic extract against nimesulide intoxicated albino rats. IJPRBS 2, 332-347.

Nadkarni, K. M. (1996). Indian Materia Medica; Dr. KM Nadkarni's Indian Materia Medica: with Ayurvedic, Unani-Tibbi, Siddha, Allopathic, Homeopathic, Naturopathic \& Home Remedies, Appendices \& Indexes. 1, Vol. 1 Mumbai: Popular Prakashan.

Omar, S. H., Scott, C. J., Hamlin, A. S., and Obied, H. K. (2017). The protective role of plant biophenols in mechanisms of Alzheimer's disease. J. Nutr. Biochem. 47, 1-20. doi: 10.1016/j.jnutbio.2017.02.016

Pahaye, D. B., Bum, E. N., Taïwé, G. S., Ngoupaye, G. T., Sidiki, N., Moto, F. C. O., et al. (2017). Neuroprotective and antiamnesic effects of Mitragyna inermis willd (Rubiaceae) on scopolamine-induced memory impairment in mice. Behav. Neurol. 2017, 1-11. doi: 10.1155/2017/5952897

Pereira, D. M., Valentão, P., Pereira, J. A., and Andrade, P. B. (2009). Phenolics: from chemistry to biology. Molecules 14, 2201-2211. doi: 10.3390/ molecules 14062202

Polshettiwar, S., Ganjiwale, R., Wadher, S., and Yeole, P. (2007). Spectrophotometric estimation of total tannins in some ayurvedic eye drops. Indian J. Pharm. sci. 69, 574-576. doi: 10.4103/0250-474X.36949

Pratico, D. (2008). Oxidative stress hypothesis in Alzheimer's disease: a reappraisal. Trends Pharmacol. sci. 29, 609-615. doi: 10.1016/j.tips.2008.09.001

Rabiei, Z., Rafieian-kopaei, M., Heidarian, E., Saghaei, E., and Mokhtari, S. (2014). Effects of Zizyphus jujube extract on memory and learning impairment induced by bilateral electric lesions of the nucleus basalis of meynert in rat. Neurochem. Res. 39, 353-360. doi: 10.1007/s11064-013-1232-8

Rajesh, V., Riju, T., Venkatesh, S., and Babu, G. (2017). Memory enhancing activity of Lawsonia inermis linn. leaves against scopolamine induced memory 
impairment in Swiss albino mice. Orient. Pharm. Exp. Med. 17, 127-142. doi: 10.1007/s13596-017-0268-8

Salomone, S., Caraci, F., Leggio, G. M., Fedotova, J., and Drago, F. (2012). New pharmacological strategies for treatment of Alzheimer's disease: focus on disease modifying drugs. Br. J. Clin. Pharmacol. 73, 504-517. doi: 10.1111/j. 1365-2125.2011.04134.x

Sinha, A. K. (1972). Colorimetric assay of catalase. Anal. Biochem. 47, 389-394. doi: 10.1016/0003-2697(72)90132-7

Sonnen, J. A., Breitner, J. C., Lovell, M. A., Markesbery, W. R., Quinn, J. F., and Montine, T. J. (2008). Free radical-mediated damage to brain in Alzheimer's disease and its transgenic mouse models. Free Radic. Biol. Med. 45, 219-230. doi: 10.1016/j.freeradbiomed.2008.04.022

Sultana, R., Perluigi, M., and Butterfield, D. A. (2013). Lipid peroxidation triggers neurodegeneration: a redox proteomics view into the Alzheimer disease brain. Free Radic. Biol. Med. 62, 157-169. doi: 10.1016/j.freeradbiomed.2012.09.027

Todd, S., Barr, S., Roberts, M., and Passmore, A. P. (2013). Survival in dementia and predictors of mortality: a review. Int. J. Geriatr. Psychiatry 28, 1109-1124. doi: $10.1002 /$ gps.3946

Tong, Y., Zhou, W., Fung, V., Christensen, M., Qing, H., Sun, X., et al. (2005). Oxidative stress potentiates BACE1 gene expression and $\mathrm{A} \beta$ generation. J. Neural. Transm. 112, 455-469. doi: 10.1007/s00702-004-0255-3
Wenk, G. L. (2003). Neuropathologic changes in Alzheimer's disease. J. Clin. Psychiatry 64, 7-10.

Wilson, D. M., and Binder, L. I. (1997). Free fatty acids stimulate the polymerization of tau and amyloid beta peptides. in vitro evidence for a common effector of pathogenesis in Alzheimer's disease. Am. J. pathol. 150:2181-2195.

Xian, Y.-F., Lin, Z.-X., Zhao, M., Mao, Q.-Q., Ip, S.-P., and Che, C.-T. (2011). Uncaria rhynchophylla ameliorates cognitive deficits induced by D-galactose in mice. Planta Med. 77, 1977-1983. doi: 10.1055/s-0031-128 0125

Conflict of Interest Statement: The authors declare that the research was conducted in the absence of any commercial or financial relationships that could be construed as a potential conflict of interest.

Copyright (C) 2018 Mushtaq, Anwar and Ahmad. This is an open-access article distributed under the terms of the Creative Commons Attribution License (CC BY). The use, distribution or reproduction in other forums is permitted, provided the original author(s) and the copyright owner(s) are credited and that the original publication in this journal is cited, in accordance with accepted academic practice. No use, distribution or reproduction is permitted which does not comply with these terms. 